\title{
Nitrogen supply from fertilizer and legume cover crop in the transition to no-tillage for irrigated row crops
}

\author{
Timothy A. Doane - William R. Horwath • \\ Jeffrey P. Mitchell · Jim Jackson · Gene Miyao • \\ Kent Brittan
}

Received: 10 September 2008/ Accepted: 10 February 2009/Published online: 19 February 2009

(C) The Author(s) 2009. This article is published with open access at Springerlink.com

\begin{abstract}
In spite of potential benefits and positive assessments of reducing primary tillage operations, only a small part of irrigated row crops is currently managed using reduced tillage, for reasons that include concerns about its agronomic suitability for certain crop rotations. Three years of a tomato/corn rotation under standard and no-tillage management were used to understand the fate of a fertilizer and cover crop nitrogen $(\mathrm{N})$ application. Uptake of both inputs was reduced under no-tillage during the year of application, in this case a tomato crop. As a result, more input $\mathrm{N}$ was retained in the soil in this system. The initial challenge of reduced tomato yields diminished as no-tillage management remained in place and the soil $\mathrm{N}$ reservoir developed. Corn production was not affected by tillage treatment. Inclusion of a legume cover crop increased the amount of fertilizer $\mathrm{N}$ retained in the soil over time, more so under no-tillage than under standard tillage,
\end{abstract}

T. A. Doane $(\varangle) \cdot$ W. R. Horwath

Department of Land, Air, and Water Resources,

University of California Davis, 1 Shields Avenue, Davis,

CA 95616, USA

e-mail: tadoane@ucdavis.edu

J. P. Mitchell · J. Jackson

Department of Plant Sciences, University of California

Davis, 1 Shields Avenue, Davis, CA 95616, USA

G. Miyao · K. Brittan

Yolo County Cooperative Extension, 70 Cottonwood

Street, Woodland, CA 95695, USA emphasizing the benefit of cover crops in reducing the amount of fertilizer required to maintain productivity. While acceptance of reduced tillage ultimately depends on economic performance, the results of this study support its agronomic viability for irrigated row crops.

Keywords Conservation agriculture .

Conservation tillage $\cdot$ Fertilizer - Irrigated row crops · Legume cover crop · Nitrogen · Nitrogen-15 ·

No-tillage

\section{Introduction}

Many alternative agricultural management systems focus on primary, intercrop tillage operations such as chiseling, ripping, and plowing. Including “conservation tillage", in which these operations are reduced, and "no-tillage", in which such operations are eliminated entirely, these systems aim to maintain crop residue on the soil surface (Unger and McCalla 1980), and to conserve soil and water (Mannering and Fenster 1983). "Conservation agriculture", a somewhat broader term, is used to describe management that includes the use of reduced disturbance planting systems, the preservation of residue, and the use of diverse crop rotations. Reduced tillage systems have been widely used in the midwest and southeastern United States to decrease soil loss caused by erosion and runoff (King 1983) and to reduce production costs 
through savings in fuel, time, labor, and machinery (Allmaras and Dowdy 1985). Other potential benefits include reduction in water use; improvements in soil hydrological properties; an increase in soil organic matter and nutrient availability; improvements in soil structure; an improved habitat for beneficial fauna; the potential to reduce weeds and crop pathogens; and a reduction in gaseous pollutants, respirable dust, and ground and surface water pollution (Baker and Laflen 1983; Blevins et al. 1983; Blevins and Frye 1993; Franzluebbers and Arshad 1996; Franzluebbers and Hons 1996; Reicosky 1997; Lal et al. 1998a, b; Baker et al. 2005). Potential problems associated with reduced tillage systems have also been identified, including increased pest pressure, greater incidence of plant disease, herbicide carryover and runoff, and increased or different weed problems (Hinkle 1983; Koskinen and McWhorter 1986; Blevins and Frye 1993). Another frequently cited potential concern is the decreased availability of plant-available nitrogen (N) due to immobilization (Rice and Smith 1984; Blevins and Frye 1993; Franzluebbers et al. 1995; Schoenau and Campbell 1996; Doran et al. 1998; Power and Peterson 1998).

While most existing research and field evaluations of reduced tillage systems have come from nonirrigated farmland, many of the same benefits are possible in irrigated row crop production. Despite these apparent advantages, it is estimated that $<1 \%$ of row crop production in California's central valley, where row crops are common, is farmed using conservation tillage practices (CTIC 2004). Diverse obstacles to adoption of reduced tillage (not necessarily particular to California) have been identified: Jolly et al. (1983) and Epplin and Tice (1986) suggest that the main barrier is start-up expense (unfavorable short-term returns), while Gebhardt et al. (1985) emphasize a lack of reliable and cost-effective weed management strategies. Adoption of reduced tillage practices requires not only changes in equipment and labor, but also considerable managerial skills (Bultena and Hoiberg 1983; Gebhardt et al. 1985; Epplin and Tice 1986): the number, timing, and order of decisions such as application of nutrients, pest control, machinery adjustments, and crop selection are more critical than under conventional tillage (Nowak 1983). In general, such alternative practices are considered if growers see a gain in net benefits (Uri 1999). A recent survey of California growers
(Mitchell et al. 2007) described the foremost obstacles to adoption of conservation tillage (the term most commonly used): lack of information, concerns about suitability for certain crop rotations, concerns about suitability for irrigated production, lack of interest in changing current practices, and concerns about the costs associated with converting.

The objective of the present study was to compare, in irrigated row crop production, the fate of a fertilizer and cover crop $\mathrm{N}$ application over three seasons between conventional (standard) tillage and newly established reduced tillage. Use of cover crops can bring increases in soil organic matter and related benefits under both types of management (Lal et al. 1998b; Veenstra et al. 2007), and can be an important part of long-term and short-term fertility programs. In developing a management approach for reduced tillage alternatives, it is important to understand the $\mathrm{N}$ supplied by as well as any interactions between fertilizer and cover crops.

\section{Materials and methods}

Site and management

In Davis, California, four crop production systems were established in 2001 on a site previously under standard tillage management for a processing tomato/ field corn rotation. The soil is classified as a fine-silty, mixed, nonacid ( $\mathrm{pH}$ 6.8-7.2), thermic Mollic Xerofluvent (mollic fluvisol under FAO classification). Annual rainfall ranges from 400 to $500 \mathrm{~mm}$, with most occurring in winter, and daytime temperature during the summer growing season averages between 30 and $35^{\circ} \mathrm{C}$. Total nitrogen ranges from 1.0 to $1.2 \mathrm{~g} \mathrm{~kg}^{-1}$ in the top $15 \mathrm{~cm}$ of soil. The four systems were designated as standard tillage (ST), standard tillage with a winter legume cover crop (STCC), conservation tillage (CT), and conservation tillage with a winter legume cover crop (CTCC). Each of these four systems was replicated in four blocks, for a total of 16 plots, each 0.12 ha. This main study was established to evaluate crop yields and changes in soil properties during the transition from standard to reduced tillage production. Table 1 gives a list of operations typical for each of these four systems, from harvest of one crop to planting of the next. Although the reduced tillage treatments are referred 
Table 1 Typical field operations from harvest of one crop to planting of the next crop for each of the four systems in this study

\begin{tabular}{|c|c|c|c|}
\hline Standard tillage (ST) & $\begin{array}{l}\text { Standard tillage with } \\
\text { cover crop (STCC) }\end{array}$ & $\begin{array}{l}\text { Conservation } \\
\text { tillage }(\mathrm{CT})\end{array}$ & $\begin{array}{l}\text { Conservation tillage } \\
\text { with cover crop (CTCC) }\end{array}$ \\
\hline \multicolumn{4}{|l|}{ Before tomato } \\
\hline Mow corn residue & Mow corn residue & Mow corn residue & Mow corn residue \\
\hline Stubble disk $(2 \times)$ & Stubble disk $(2 \times)$ & Winter herbicide & Plant cover crop \\
\hline Finishing disk & Finishing disk & & Chop cover crop \\
\hline Moldboard plow & Moldboard plow & & Herbicide \\
\hline Rip/subsoil & Rip/subsoil & & \\
\hline Landplane & Landplane & & \\
\hline List beds & List beds & & \\
\hline Winter herbicide & Plant cover crop & & \\
\hline Bed cultivator & Chop cover crop & & \\
\hline Herbicide + bed mulch & Bed disk $(2 \times)$ & & \\
\hline Roll beds & $\begin{array}{l}\text { Herbicide }+ \text { bed mulch } \\
\text { Roll beds }\end{array}$ & & \\
\hline \multicolumn{4}{|l|}{ Before corn } \\
\hline Stubble disk tomato $(2 \times)$ & Stubble disk $(2 \times)$ & Winter herbicide & Plant cover crop \\
\hline Landplane & Landplane & & Chop cover crop \\
\hline List beds & List beds & & Herbicide \\
\hline Winter herbicide & Plant cover crop & & \\
\hline Bed cultivator & $\begin{array}{l}\text { Disk cover crop } \\
\text { List beds }\end{array}$ & & \\
\hline
\end{tabular}

to here as "conservation tillage", a term currently widely used in California, these treatments are in effect "no-tillage" systems, since they employ no primary tillage operations, the only disturbance being shallow, surface cultivation used during the tomato growing season.

One important difference in operations between standard and conservation tillage, other than plowing, is the omission of leveling ("landplane") from the CT plots, an operation which maintains slope characteristics for irrigation. While there is a risk of problems building up over time in the CT plots, two things work to reduce the need for leveling. First, there is substantially less soil disturbance in the CT plots, and therefore less accumulated need to "relevel" the soil. Second, the furrows are maintained periodically: furrow sweeps, for example, are fitted to the tomato transplanter to clean the furrows at the beginning of the season, effectively "releveling" the furrows.

Superimposed onto the main study, microplots measuring $9 \mathrm{~m}^{2}$ were established in the spring of 2002 in all 16 main plots. Each microplot encompassed three beds, and each bed measured $3 \mathrm{~m}$ long and $1 \mathrm{~m}$ wide and contained one row of tomato plants or two rows of corn plants. These microplots received $\mathrm{N}$ additions as shown in Table 2.

Ammonium sulfate fertilizer was applied to both the main plots and the microplots in an amount equivalent to $140 \mathrm{~kg} \mathrm{~N} \mathrm{ha}^{-1}$. The winter legume cover crop, vetch (Vicia sativa), was applied to the appropriate microplots. Nitrogen-15-labeled vetch was applied in an amount equivalent to $140 \mathrm{~kg} \mathrm{~N}$ $\mathrm{ha}^{-1}$, and unlabeled vetch at an amount equivalent to $120 \mathrm{~kg} \mathrm{~N} \mathrm{ha}^{-1}$. This difference in application rate resulted from the fact that while equal weights were applied, later analysis showed a higher $\mathrm{N}$ content of the labeled vetch. Labeled vetch was grown during the previous winter in a nearby field by foliar spray of ${ }^{15} \mathrm{~N}$ solution (as ammonium and nitrate) two separate times during its growth; the final enrichment of this vetch was 1.3 atom $\%{ }^{15} \mathrm{~N}$. Unlabeled vetch was harvested at the same time from an adjacent field.

To prepare the vetch for application, the total amount of material (labeled or unlabeled) was gathered, chopped into pieces $20-30 \mathrm{~cm}$ in length, and mixed well. That which was to be applied to STCC 
Table 2 Nitrogen inputs applied to the microplots in the standard and conservation tillage main plots

\begin{tabular}{lll}
\hline System & Microplot & Nitrogen inputs \\
\hline Standard tillage & ST ${ }^{\mathrm{a}} \mathrm{F}$ & ${ }^{15} \mathrm{~N}$-labebed fertilizer \\
& Unamended & None \\
Standard tillage with cover crop & STCC ${ }^{\mathrm{a}} \mathrm{F}+\mathrm{V}$ & ${ }^{15} \mathrm{~N}$-labeled fertilizer + unlabeled vetch \\
& STCC ${ }^{\mathrm{a}} \mathrm{V}+\mathrm{F}$ & ${ }^{15} \mathrm{~N}-$ labeled vetch + unlabeled fertilizer \\
& Unamended & None \\
Conservation tillage & $\mathrm{CT}{ }^{\mathrm{a} F}$ & ${ }^{15} \mathrm{~N}$-labebed fertilizer \\
Conservation tillage with cover crop & Unamended & None \\
& $\mathrm{CTCC}{ }^{a} \mathrm{~F}+\mathrm{V}$ & ${ }^{15} \mathrm{~N}-$ labeled fertilizer + unlabeled vetch \\
& $\mathrm{CTCC}{ }^{\mathrm{a}} \mathrm{V}+\mathrm{F}$ & ${ }^{15} \mathrm{~N}-$ labeled vetch + unlabeled fertilizer \\
& Unamended & None \\
\hline
\end{tabular}

${ }^{\text {a }}$ Input contained ${ }^{15} \mathrm{~N}$

Sample collection and analysis

better raked clean, and the preweighed amount of vetch was spread onto each of the three beds in the microplot and incorporated with a small tractor-mounted rototiller. The CTCC microplots were cleaned, and the vetch applied and then pinned down with a shovel into the soil. Vetch was applied 10 days before transplanting tomato seedlings.

For the application of sidedress fertilizer to a microplot receiving unlabeled fertilizer, two "shank lines" were opened with a shovel in each of the three beds. In the two border beds, a preweighed cup of granular ammonium sulfate was spread in these shank lines. In the middle bed, this application was broken up into three 1-meter segments per line for greater accuracy. In the microplots receiving labeled fertilizer, a small aliquot of ${ }^{15} \mathrm{~N}$-ammonium sulfate solution was mixed with the ammonium sulfate granules in each preweighed cup, mixed, and the cup then spread uniformly into each of the six segments of the middle bed. To save time in the two border beds, the aliquot of ${ }^{15} \mathrm{~N}$-ammonium sulfate was dispensed directly on top of the ammonium sulfate granules with a pipet. The overall atom $\%{ }^{15} \mathrm{~N}$ of the labeled fertilizer was 2.1 . Fertilizer was applied 3 weeks after transplanting.

The microplots were managed like the main plots throughout the study, being fertilized and cover cropped in subsequent years. The unamended microplots were kept free of $\mathrm{N}$ inputs. The labeled inputs mentioned above were thus only applied once, in the spring of 2002, and it was this application that was traced through subsequent seasons. Processing tomatoes (from transplants) were grown in 2002, field corn in 2003, and tomatoes again in 2004.
At tomato harvest in August 2002 (when the greatest possible number of fruits had turned red but overripe fruits were still minimal), the three center plants from the middle bed of each microplot were cut, and the red (marketable) fruits separated from the unripe, rotten, and damaged fruits. The fruits and vines (residue) were weighed in the field and a subsample of each saved for analysis. The vines and unmarketable fruits were returned to their respective microplots. Due to delayed fruit maturity in the CT plots, these plots were harvested a week after the ST plots, in an attempt to maximize the amount of marketable fruit. Marketable fruit (an export) was removed from the rest of the plants in all microplots. Soil samples were taken after harvest in each system. Ten $2.5-\mathrm{cm}$ cores to a depth of $30 \mathrm{~cm}$ were taken evenly across the center area of each microplot, composited, sieved to $4 \mathrm{~mm}$, and air-dried.

The vine subsamples were oven-dried, coarsely ground in a Wiley mill, and a subsample of this material was finely ground in ball-milling cylinders. Samples were analyzed for total $\mathrm{N}$ and ${ }^{15} \mathrm{~N}$ content by continuous flow combustion-GC-IRMS (ANCA, Europa). Tomato fruit subsamples were homogenized in a blender, and an aliquot $(\sim 50 \mathrm{ml})$ of this liquid was freeze-dried. Water content was determined by weighing before and after drying. The freeze-dried tomato pulp was then ground to a fine powder in ballmilling cylinders and analyzed for $\mathrm{N}$ and ${ }^{15} \mathrm{~N}$. A subsample of the soil collected was ball-milled and analyzed for $\mathrm{N}$ and ${ }^{15} \mathrm{~N}$.

At corn harvest in October 2003, three plants from the center of each microplot were removed and 
separated into grain and residue. These were ovendried, ground, and analyzed as described above. Soil samples were also taken from the center area of each microplot. In August 2004, the microplots were again harvested. To convert data from microplots (results per plant) into units of $\mathrm{kg} \mathrm{ha}^{-1}$, the number of plants per hectare was determined each year from plant stand counts.

\section{Results}

In each of the figures referred to below, different letters indicate significant differences (ANOVASNK, $P<0.05)$ between treatments within a given year. Figure 1 gives the microplot crop yields for each year of the study. Main plot yields estimated by machine harvest showed the same trends as the microplot yields, although they were about $50 \%$ higher for the tomato harvests (data not shown). Tomato yields were impacted by tillage system management, with yields in the ST and STCC plots at least $30 \%$ higher than the CT or CTCC plots; differences between treatments were significant in 2002 but not in 2004. Corn yields, in contrast, were not affected by tillage system.

Figure 2 shows the amount of $\mathrm{N}$ removed as marketable tomatoes or corn grain. Total export during the 3 years of this study (each bar in the graph) is split up by year. These $\mathrm{N}$ data reflect the same trends as crop yield (Fig. 1).
The amount of the original input of tracer $\mathrm{N}$ in 2002 (as fertilizer or vetch) which was present in the aboveground crop biomass after each season is shown in Fig. 3. In 2002, the CT tomato crop took up about half as much fertilizer $\mathrm{N}$ as did the ST crop. In 2003, both CT and ST corn crops recovered a similar amount of the 2002 fertilizer $\mathrm{N}$ input. The presence of vetch increased the average amount of fertilizer $\mathrm{N}$ taken up in 2002 by approximately one-third in both systems (compare ST *F with STCC *F+V or CT *F with CTCC *F+V), although this increase was not significant. Recovery the following year of the original fertilizer input, however, dropped by approximately two-thirds in both ST and CT when vetch was part of the system (compare the same pairs of microplots in 2003).

It is interesting to note in Fig. 3 that when only fertilizer was applied, the amount of the original $\mathrm{N}$ input recovered in the 2003 ST crop was about half of that recovered in 2002, while in the CT microplots, it was slightly greater (compare 2002 and 2003 bars within $\mathrm{ST} * \mathrm{~F}$ and within $\mathrm{CT} * \mathrm{~F})$. A similar observation was made between the STCC and CTCC microplots with respect to vetch $\mathrm{N}$ recovery. If fertilizer and vetch are together considered the "total $\mathrm{N}$ amendment" in the cover cropped systems, second-year residual uptake (in 2003) of total amendment $\mathrm{N}$ (applied in 2002) was comparable in all four systems. For example, uptake of fertilizer $\mathrm{N}$ in STCC plus uptake of vetch N in STCC was similar to uptake of fertilizer N in ST. By the 2004 harvest,
Fig. 1 Crop yield from the microplots established in standard tillage and conservation tillage main plots. Microplot abbreviations are described in Table 2

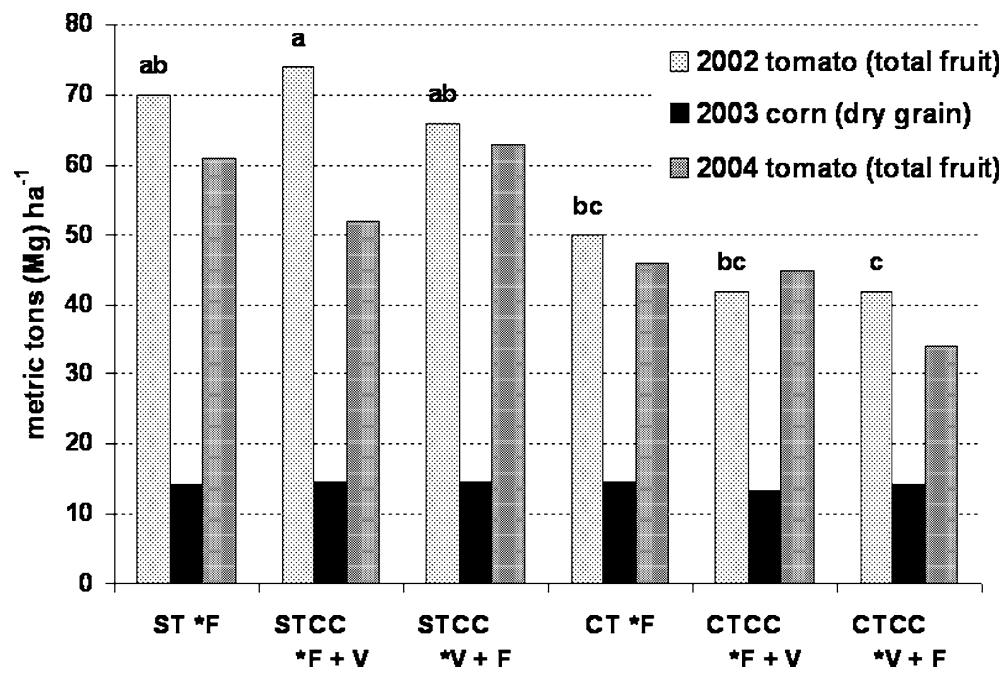


Fig. 2 Total nitrogen exported from each treatment at harvest (removal of the harvested portion of each cropmarketable tomatoes or corn grain). Microplot abbreviations are described in Table 2
Fig. 3 Recovery in the aboveground biomass of subsequent crops of the original ${ }^{15} \mathrm{~N}$-labeled input $(* F$, fertilizer or $* V$, vetch) applied in spring 2002 to each treatment (see Table 2)
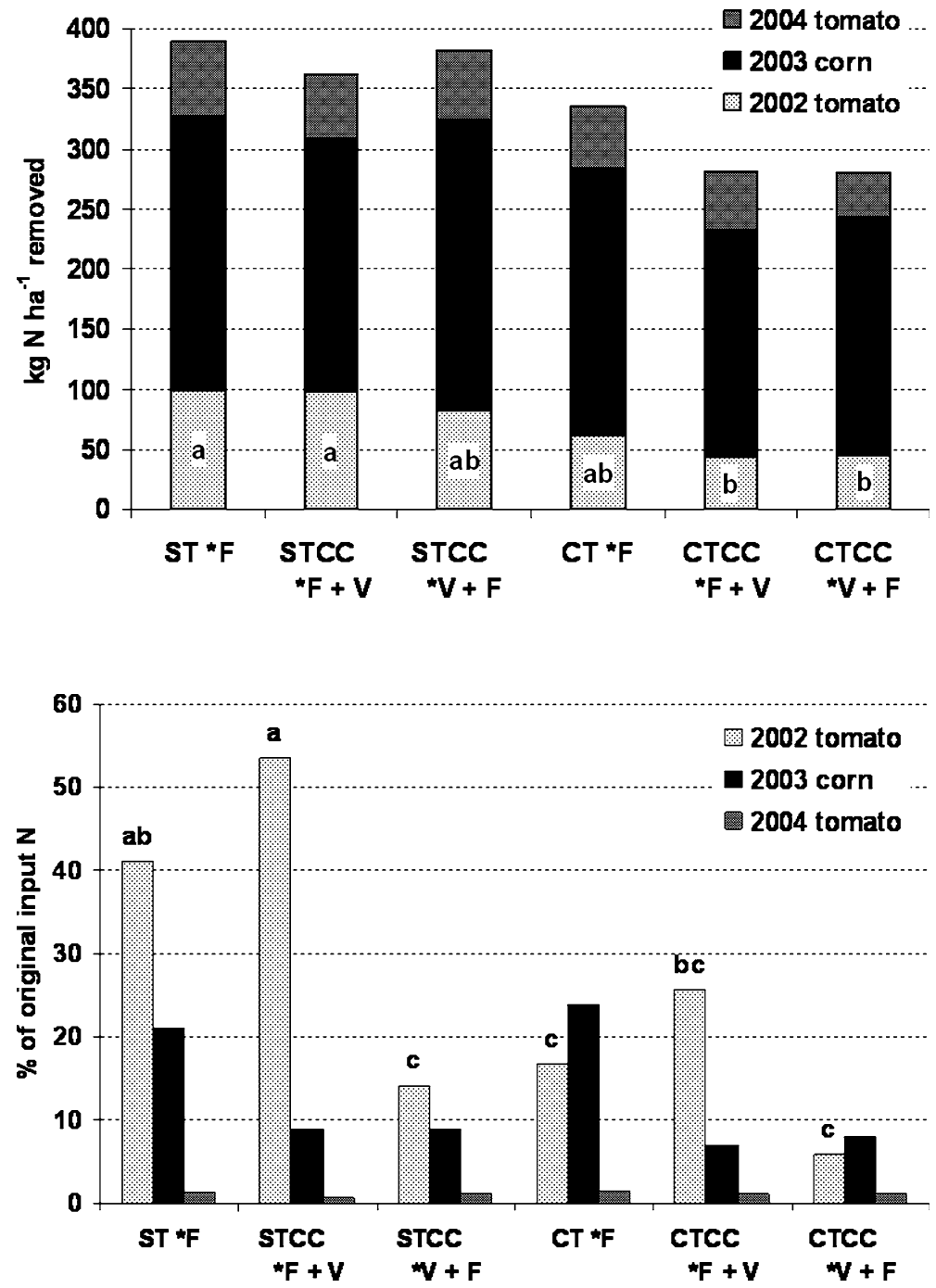

$<2 \%$ of the original input $\mathrm{N}$ in any treatment was recovered by the tomato crop.

Figure 4 shows how much of the 2002 input $\mathrm{N}$ was still present in the soil at the end of each subsequent season. At the end of three seasons, more of the original input $\mathrm{N}$ remained in the soil under $\mathrm{CT}$ management. This is related in part to greater crop uptake (and hence removal) of this $\mathrm{N}$ under ST management. It is notable in Fig. 4 that from fall 2002 to fall 2003, after a corn crop, more than half of the original input-derived $\mathrm{N}$ was lost from the soil in the ST systems. In contrast, in the CT plots, more loss occurred from fall 2003 to fall 2004, after the second tomato crop. The inclusion of vetch had a marked influence on the fate of fertilizer, almost doubling the amount of fertilizer-derived $\mathrm{N}$ remaining in the CT plots after three seasons (compare CT $* \mathrm{~F}$ with $\mathrm{CT}$ $* \mathrm{~F}+\mathrm{V})$. The effect of vetch was much smaller in the ST system.

The unamended microplots (Fig. 5), while only a hypothetical treatment, were nevertheless used to evaluate the capacity of the soil itself to supply $\mathrm{N}$ to a crop under changing tillage management. Unamended ST-managed soil showed significantly more $\mathrm{N}$ available to the 2002 tomato crop than CT, although by 2004 the supplying power of the ST soil to the tomato crop had declined, by proportionately more than that of CT-managed soil. The unamended CT plots already had less than half the $\mathrm{N}$ supplying power of the ST plots in the 2002 season. 
Fig. 4 Percent remaining in soil (top $30 \mathrm{~cm})$ at harvest of the original ${ }^{15} \mathrm{~N}$-labeled (*) input $\mathrm{N}$ applied in spring 2002 to each treatment (see Table 2)
Fig. 5 Total nitrogen in the aboveground crop in the unamended treatments, corresponding to uptake of soil $\mathrm{N}$ alone
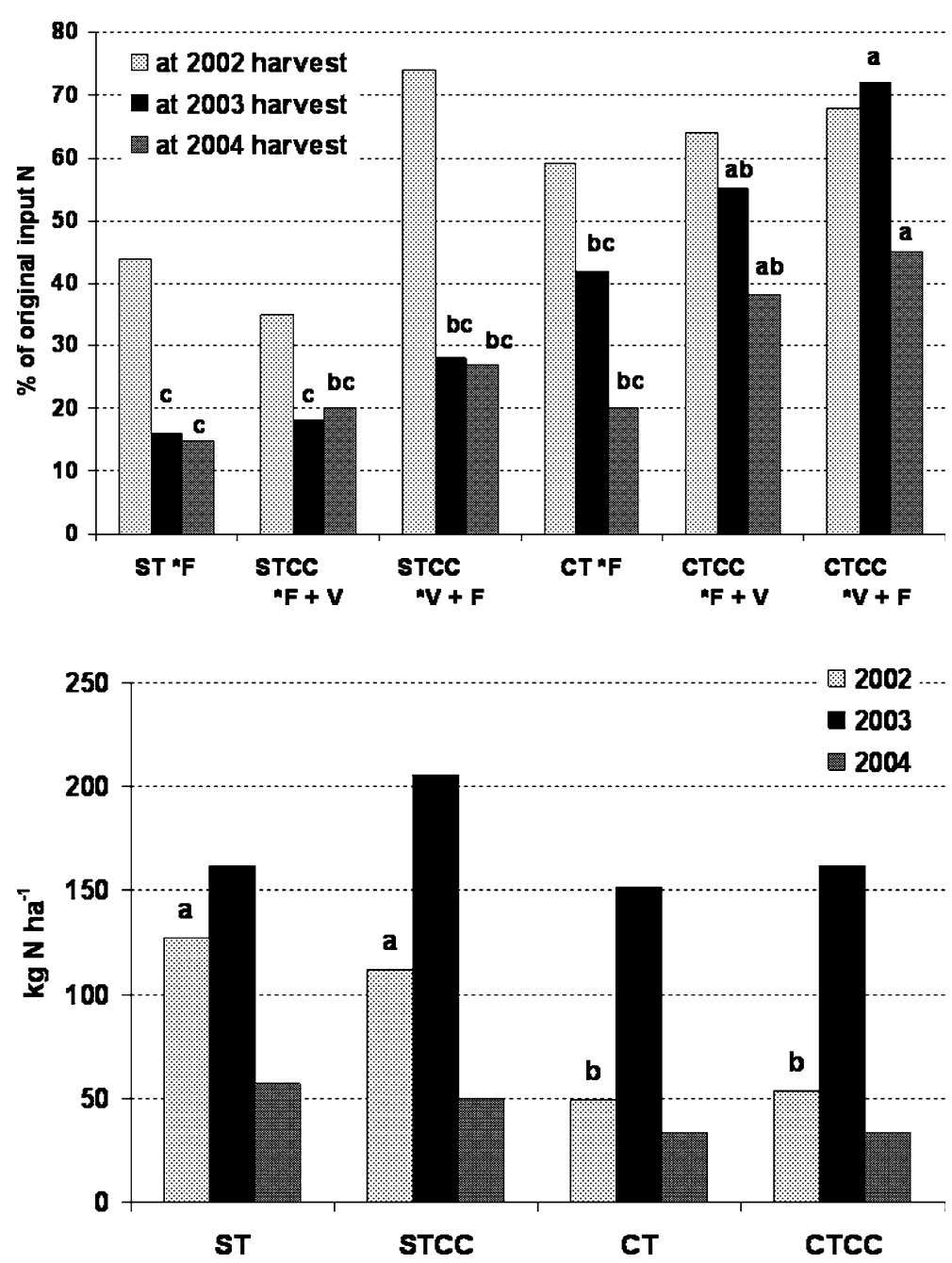

\section{Discussion}

Nitrogen availability

The lower yields in CT tomato at our site may have been caused in part due to a temporary lack of available $\mathrm{N}$, a recognized concern in $\mathrm{CT}$ production. This challenge during conversion from ST to CT, however, seemed to improve as CT remained in place, even though our data reflect only 3 years of this transition. Zibilske et al. (2002) also reported results consistent with slow gains in soil fertility for a cotton/corn rotation. Tessier et al. (1990) describe initial lower soil $\mathrm{N}$ fertility under no-tillage compared to standard tillage, although this also tended to improve with time; reduced fertility in this study did not seem to limit crop production. Similarly, Karlen
(1990) mentions that while fertilizer use efficiency may be lower initially due to increased immobilization under reduced tillage, soil and fertilizer $\mathrm{N}$ will be conserved as soil organic matter is built up, and fertilizer requirements may decrease over time.

Cover crops and reduced tillage

Whether limiting to crop growth or not, the timing and amount of decomposition and $\mathrm{N}$ release from legume cover crops are known to be affected by tillage regime (Groffman et al. 1987; Huntington et al. 1985; Varco et al. 1989). The use of a cover crop was especially favorable to management of $\mathrm{N}$ fertility in our reduced tillage system. First, the inclusion of vetch increased the amount of fertilizer $\mathrm{N}$ retained in the CT plots. Second, in spite of obvious differences (incorporation 
into the soil in STCC versus the potential for volatilization and physical loss from the surface in CTCC) the amount of the cover crop $\mathrm{N}$ application remaining in the CT plots after one season (2002) was not different from that remaining in the ST plots. Third, in the years following its application, significantly more vetch-derived $\mathrm{N}$ remained in the soil under CT management. Finally, the decrease in recovery of vetch-derived $\mathrm{N}$ from 2002 to 2003 in the STCC soil (Fig. 4) points to a large loss of this N during this time, while no such loss was observed in the CTCC plots.

As suggested by others (Touchton et al. 1982, 1984; Hargrove 1986; Blevins and Frye 1993; Reeves et al. 1993; Abdul-Baki et al. 1997; Sainju et al. 2002), for reduced tillage systems that include winter legume cover crops, the crop fertilizer requirement can diminish with successive seasons, and fertilizer rates can often be appreciably reduced. This may be due directly to the release of cover crop $\mathrm{N}$, as well as indirectly through build up of organic matter and improved recycling of $\mathrm{N}$ inputs. Figure 4 shows that the inclusion of vetch almost doubled the amount of fertilizer $\mathrm{N}$ retained in the soil after three seasons, evidence that after several years, fertilizer applications could be reduced in the CTCC system without any negative effects on production. As stated by Hargrove (1986), since fertilizer $\mathrm{N}$ can represent a large part of the fossil fuel energy needed for crop production, the $\mathrm{N}$ supplied by a legume cover crop corresponds to energy savings, thereby "enhancing the conservation value" of reduced tillage systems. Whether or not the use of cover crops will prove profitable depends on the relative cost of introducing a cover crop into the rotation versus the value of the benefits it brings. Winter legume cover crops are worth considering for their ability to support long-term soil fertility in reduced tillage systems such as ours.

\section{Other tillage management issues}

A notable issue at our study site was the slower maturity of the tomato crop under reduced tillage. This early season lack of vigor could be due to reduced $\mathrm{N}$ availability, planting problems related to uneven beds, or the effects of crop residues such as lower soil temperature and allelopathy. Thomas et al. (2001) also reported how some of these problems might limit the utility of CT for processing tomatoes.
In our study, optimizing the time of harvest could improve tomato yields to some extent in CT, although they remained lower than under ST.

Overall performance of standard versus reduced tillage

Cosper (1983), in discussing the "significant, selective relationship" between soils and tillage management, notes that on soils which respond to tillage and surface cover (as indicated by crop yield), tillage intensity must increase as surface cover decreases in order to maintain yields. Karlen (1990) comments that practices designed to improve nutrient use should consider not only the tillage regime but also how long such practices have been in use. Acceptance of reduced tillage management ultimately depends on overall performance, i.e., net returns (Mueller et al. 1985; Smart and Bradford 1999), even if yields are lower than with standard tillage. While an economic evaluation was not the objective of our study, it is clear from Table 1 that overall expenditures are less under CT management. Although tomato yielded less at our site during the transition to $\mathrm{CT}$, successful CT tomato systems have recently been demonstrated in California (Mitchell et al. 2008), and refinement and further evaluation of such management options is warranted.

\section{Conclusion}

In spite of its many recognized benefits, it is hard to unconditionally recommend reduced tillage for any site because of variable crop response to tillage and other factors such as soil type, climate, crop rotation, and management history. This study aimed to describe some characteristics of fertilizer and cover crop $\mathrm{N}$ inputs in a tomato/corn rotation so as to begin to identify strategies for optimizing reduced tillage systems in irrigated row crops. Under reduced tillage, more of a fertilizer or vetch $\mathrm{N}$ application was retained in the soil reservoir after three seasons. The compromise was reduced tomato yield, since both inputs were used less efficiently as sources of $\mathrm{N}$ by this crop compared to standard tillage. Corn did not show any such apparent limitations in $\mathrm{N}$ availability, making it a better choice, at least agronomically, during the establishment of reduced tillage management at our site. Also notable was the indication, in agreement with other studies, that 
including a legume cover crop in a reduced tillage system could decrease the amount of fertilizer required to maintain productivity. Our study is only one data set tracing one $\mathrm{N}$ application; lack of experience meant that management was perhaps less than ideal at times. Together with other well-documented benefits, however, it substantiates reduced tillage as a management option for irrigated row crop agriculture.

Acknowledgments The assistance of N. Madden and M. Martinez with field operations is gratefully acknowledged. Nitrogen-15 analyses were performed by the Stable Isotope Facility at UC Davis. The helpful comments of two reviewers are appreciated.

Open Access This article is distributed under the terms of the Creative Commons Attribution Noncommercial License which permits any noncommercial use, distribution, and reproduction in any medium, provided the original author(s) and source are credited.

\section{References}

Abdul-Baki AA, Teasdale JR, Korcak RF (1997) Nitrogen requirements of fresh-market tomatoes on hairy vetch and black polyethylene mulch. HortScience 32:217-221

Allmaras RR, Dowdy RH (1985) Conservation tillage systems and their adoption in the United States. Soil Tillage Res 5:197-222. doi:10.1016/0167-1987(85)90030-3

Baker JL, Laflen JM (1983) Water quality consequences of conservation tillage. J Soil Water Conserv 38:186-193

Baker JB, Southard RJ, Mitchell JP (2005) Agricultural dust production in standard and conservation tillage systems in the San Joaquin Valley. J Environ Qual 34:1260-1269. doi: $10.2134 /$ jeq2003.0348

Blevins RL, Frye WW (1993) Conservation tillage: an ecological approach to soil management. Adv Agron 51:3378. doi:10.1016/S0065-2113(08)60590-8

Blevins RL, Smith MS, Thomas GW, Frye WW (1983) Influence of conservation tillage on soil properties. J Soil Water Conserv 38:301-305

Bultena G, Hoiberg EO (1983) Factors affecting farmers' adoption of conservation tillage. J Soil Water Conserv 38: 281-284

Cosper HR (1983) Soil suitability for conservation tillage. J Soil Water Conserv 38:152-155

CTIC (2004) National crop residue management survey. Conservation Technology Information Center, West Lafayette

Doran JW, Elliott ET, Paustian K (1998) Soil microbial activity, nitrogen cycling, and long-term changes in organic carbon pools as related to fallow tillage management. Soil Tillage Res 49:3-18. doi:10.1016/S0167-1987(98)00150-0

Epplin FM, Tice TF (1986) Influence of crop and farm size on adoption of conservation tillage. J Soil Water Conserv 41:424-427
Franzluebbers AJ, Arshad MA (1996) Water-stable aggregation and organic matter in four soils under conventional and zero tillage. Can J Soil Sci 76:387-393

Franzluebbers AJ, Hons FM (1996) Soil profile distribution of primary and secondary plant-available nutrients under conventional and no tillage. Soil Tillage Res 39:229-239. doi:10.1016/S0167-1987(96)01056-2

Franzluebbers AJ, Hons FM, Zuberer DA (1995) Tillage and crop effects on seasonal soil carbon and nitrogen dynamics. Soil Sci Soc Am J 59:1618-1624

Gebhardt MR, Daniel TC, Schweizer EE, Allmaras RR (1985) Conservation tillage. Science 230:625-630. doi:10.1126/ science.230.4726.625

Groffman PM, Hendrix PF, Crossley DA (1987) Nitrogen dynamics in conventional and no-tillage agroecosystems with inorganic fertilized or legume nitrogen inputs. Plant Soil 97:315-332. doi:10.1007/BF02383222

Hargrove WL (1986) Winter legumes as a nitrogen source for no-till grain sorghum. Agron J 78:70-74

Hinkle MK (1983) Problems with conservation tillage. J Soil Water Conserv 38:201-206

Huntington TG, Grove JH, Frye WW (1985) Release and recovery of nitrogen from winter annual cover crops in no-till corn production. Commun Soil Sci Plant Anal 16:193-211. doi:10.1080/00103628509367596

Jolly RW, Edwards WM, Erbach DC (1983) Economics of conservation tillage in Iowa. J Soil Water Conserv 38: 291-294

Karlen RL (1990) Conservation tillage research needs. J Soil Water Conserv 45:365-369

King AD (1983) Progress in no-till. J Soil Water Conserv 38:160-161

Koskinen WC, McWhorter CG (1986) Weed control in conservation tillage. J Soil Water Conserv 41:365-370

Lal R, Kimble JM, Follett RF, Cole CV (eds) (1998a) The Potential of U.S. Cropland to Sequester Carbon and Mitigate the Greenhouse Effect. Sleeping Bear Press Inc., Ann Arbor

Lal R, Kimble JM, Follett RF, Stewart BA (eds) (1998b) Management of Carbon Sequestration in Soil. CRC Press, Boca Raton

Mannering JV, Fenster CR (1983) What is conservation tillage? J Soil Water Conserv 38:141-143

Mitchell JP, Klonsky K, Shrestha A, Fry R, DuSault A, Beyer J, Harben R (2007) Adoption of conservation tillage in California: current status and future perspectives. Aust $\mathrm{J}$ Exp Agric 47:1383-1388. doi:10.1071/EA07044

Mitchell JP, Southard RJ, Madden NM, Klonsky KM, Baker JB, DeMoura RL, Horwath WR, Munk DS, Wroble JF, Hembree KJ, Wallender WW (2008) Transition to conservation tillage evaluated in San Joaquin Valley cotton and tomato rotations. Calif Agric 62:74-79

Mueller DH, Klemme RM, Daniel TC (1985) Short- and longterm cost comparisons of conventional and conservation tillage systems in corn production. J Soil Water Conserv 40:466-470

Nowak PJ (1983) Obstacles to adoption of conservation tillage. J Soil Water Conserv 38:162-165

Power JF, Peterson GA (1998) Nitrogen transformations, utilization, and conservation as affected by fallow tillage method. Soil Tillage Res 49:37-47. doi:10.1016/S01671987(98)00153-6 
Reeves DW, Wood CW, Touchton JT (1993) Timing nitrogen applications for corn in a winter legume conservationtillage system. Agron J 85:98-106

Reicosky DC (1997) Tillage-induced $\mathrm{CO}_{2}$ emission from soil. Nutr Cycl Agroecosyst 49:273-285. doi:10.1023/A:10097 66510274

Rice CW, Smith MS (1984) Short-term immobilization of fertilizer $\mathrm{N}$ at the surface of no-till and plowed soils. Soil Sci Soc Am J 48:295-297

Sainju UM, Singh BP, Yaffa S (2002) Soil organic matter and tomato yield following tillage, cover cropping, and nitrogen fertilization. Agron J 94:594-602

Schoenau JJ, Campbell CA (1996) Impact of crop residues on nutrient availability in conservation tillage systems. Can J Plant Sci 76:621-626

Smart JR, Bradford JM (1999) Conservation tillage corn production for a semiarid, subtropical environment. Agron J 91:116-121

Tessier S, Peru M, Dyck FB, Zentner FP, Campbell CA (1990) Conservation tillage for spring wheat production in semiarid Saskatchewan. Soil Tillage Res 18:73-89. doi:10.1016/ 0167-1987(90)90094-T

Thomas R, O’Sullivan J, Hamill A, Swanton CJ (2001) Conservation tillage systems for processing tomato production. HortScience 36:1264-1268
Touchton JT, Gardner WA, Hargrove WL, Duncan RR (1982) Reseeding crimson clover as a $\mathrm{N}$ source for no-tillage grain sorghum production. Agron J 74:283-287

Touchton JT, Rickerl DH, Walker RH, Snipes CE (1984) Winter legumes as a nitrogen source for no-tillage cotton. Soil Tillage Res 4:391-401. doi:10.1016/0167-1987(84) 90038-2

Unger PW, McCalla RM (1980) Conservation tillage systems. Adv Agron 33:1-58. doi:10.1016/S0065-2113(08)60163-7

Uri ND (1999) Factors affecting the use of conservation tillage in the United States. Water Air Soil Pollut 116:621-638. doi:10.1023/A:1005168928627

Varco JJ, Frye WW, Smith MS, MacKown CT (1989) Tillage effects on nitrogen recovery by corn from a nitrogen-15 labeled legume cover crop. Soil Sci Soc Am J 53:822-827

Veenstra JJ, Horwath WR, Mitchell JP (2007) Tillage and cover cropping effects on aggregate-protected carbon in cotton and tomato. Soil Sci Soc Am J 71:362-371. doi: 10.2136/sssaj2006.0229

Zibilske LM, Bradford JM, Smart JR (2002) Conservation tillage induced changes in organic carbon, total nitrogen and available phosphorus in a semi-arid alkaline subtropical soil. Soil Tillage Res 66:153-163. doi:10.1016/ S0167-1987(02)00023-5 